\title{
Transformation of the street network of Diocletian's Palace
}

\author{
T. Marić \& B. B. O. Šćitaroci \\ Department of Urban and Spatial Planning and Landscape Architecture, \\ Faculty of Architecture, University of Zagreb, Croatia
}

\begin{abstract}
Diocletian's Palace is the urban core of the city of Split and it was built in the late $4^{\text {th }}$ century $\mathrm{AD}$ as a unique Roman building. Cardo and decumanus streets formed the main functional and compositional basis of the Palace and later of the city. In the Renaissance and the Baroque period, the medieval core of the city was enclosed by a new system of fortifications. They were demolished in the $19^{\text {th }}$ century enabling the city to re-define its growth and re-create its open spaces. In the $20^{\text {th }}$ century the city rapidly developed and Diocletian's Palace with its medieval periphery (since 1979 part of the UNESCO World Heritage list) became the historical and public centre of Split. This paper analyses transformations of the urban street network in the context of creating vital and human scaled public places. These transformations correlate with the historical urban structure and function, especially fortification. Open spaces reserved and regained from the fortifications give a spatial basis for the urban transformation along with the revival and enhancement of urban landscape and street network. The historical value of cultural heritage provides foundation and additional reasons for generic streets to become an important network of contemporary public places where people gather and stay, stroll and walk, learn and play, or generally feel comfortable.

Keywords: Diocletian's Palace, Split, Croatia, street network, public space, lungomare, placemakin, human scale.
\end{abstract}

\section{Introduction}

The city of Split is a Mediterranean city in the middle of the Adriatic coast in Croatia whose urban heritage dates back to the Roman period. Here at the Split 
peninsula Diocletian built his Palace in the period around 395-405 AD (fig. 1, 2 ). The complex is a combination of a luxurious villa and a roman military city form known as castrum, where cardo and decumanus streets formed the main organisational structure. Over a long period of time the Palace slowly became a city and this historical city became the city centre of contemporary Split (fig. 3). The main purpose of this research is to explore the transformation of streets and urban pathways through history in the context of creating vital and vivid urban network of public places. Therefore, the goals of this paper are to show: (1) how the urban heritage with the focus on the Palace has influenced the creation of two, inner and outside, systems of public connection to the city peripheries; (2) that independent network has transformed from the open urban space of motion into the public places of the city centre; (3) elements of this network that connect parts of the city form connections with the city parts.

This research is a part of the scientific project Heritage Urbanism - Urban and Spatial Planning Models for Revival and Enhancement of Cultural Heritage (2032) financed by Croatian Science Foundation, which is being carried out at the Faculty of Architecture, University of Zagreb, under the project leadership of Prof. Dr. Sc. Mladen Obad Šćitaroci.

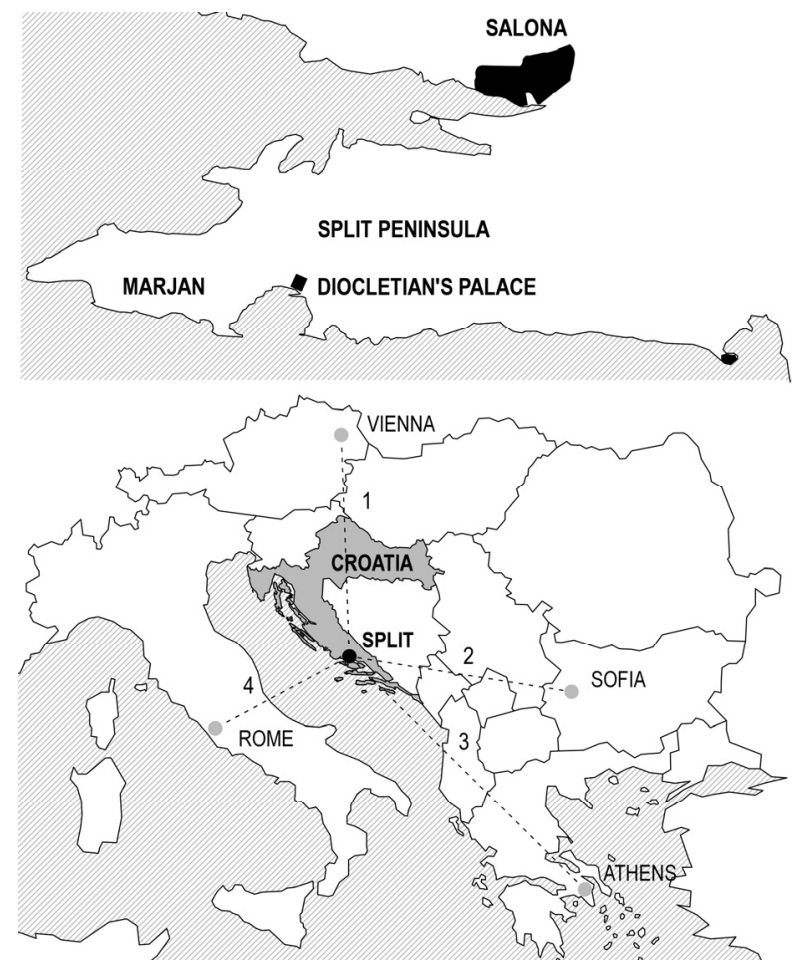

Figure 1: The city of Split - location and air distances: 1 - from Vienna 523 $\mathrm{km} ; 2$ - from Sofia $566 \mathrm{~km} ; 3$ - from Athens $869 \mathrm{~km} ; 4$ - from Rome $372 \mathrm{~km}$. 


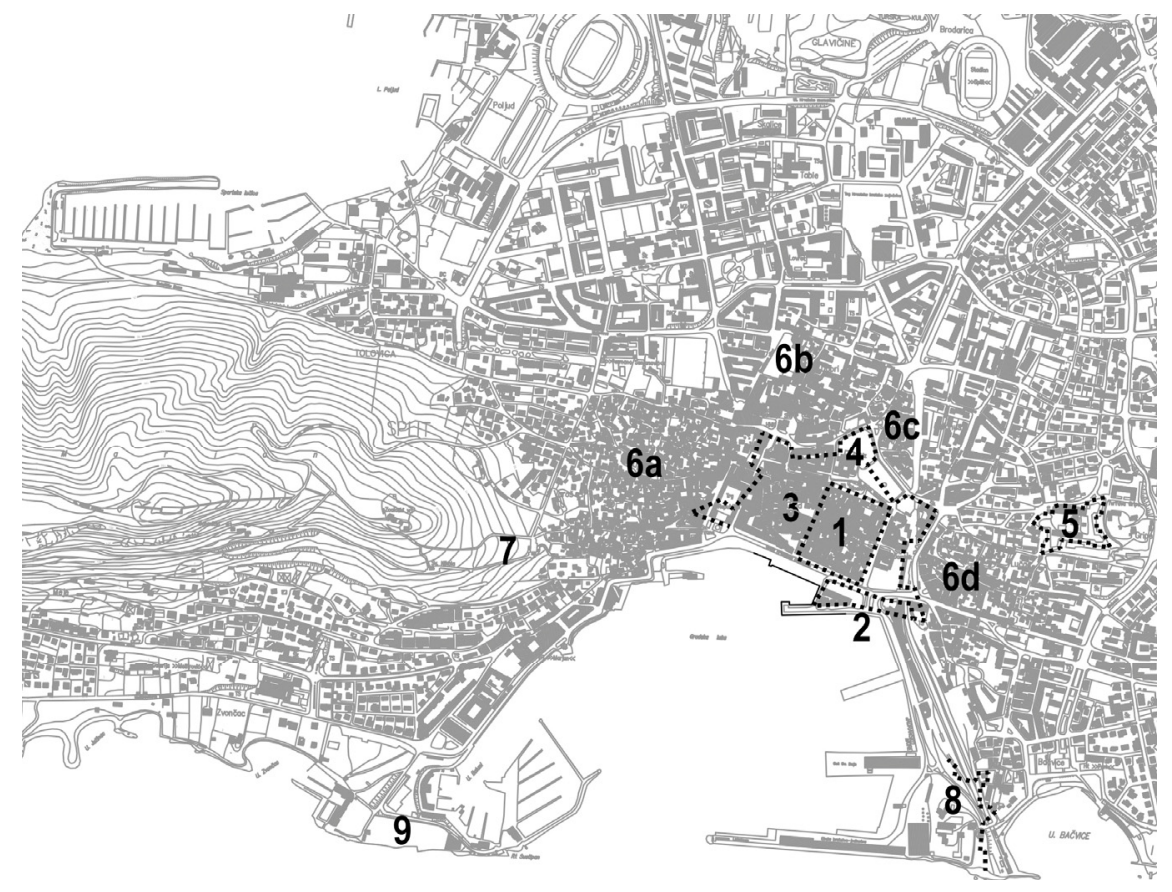

Figure 2: Urban historical parts of the city of Split.

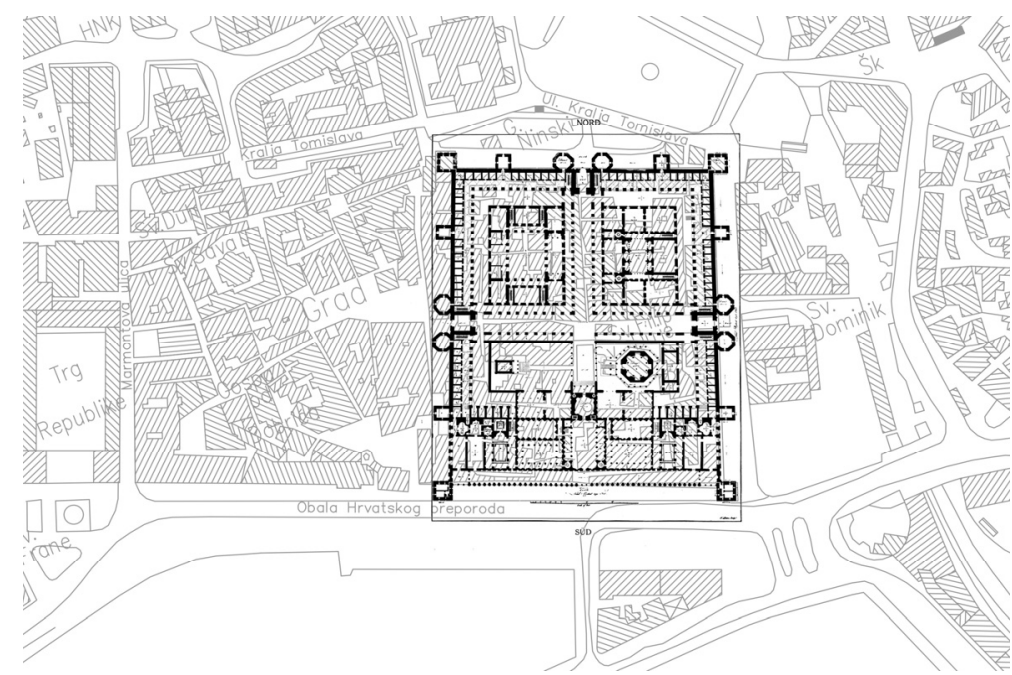

Figure 3: Diocletian's Palace in the urban core of Split (R. Adam plan of the Palace from 1764 placed on contemporary HOK - Croatian Base Map). 


\section{Research background}

\subsection{Historical background: development of the city of Split}

In the $6^{\text {th }}$ century $\mathrm{AD}$ residents of a nearby historical Roman city and port Salona fled from the Avar invasion, settling in the former royal palace situated at that time on the periphery of Salona. They transformed the Palace into a medieval burg. During a slow and gradual growth the city doubled its area to the west. At the beginning, main roads connected two and then four nearby peripheral suburbs with the city. In Renaissance and Baroque times, the city was enclosed by a system of fortifications, which were demolished in the $19^{\text {th }}$ century during the short French rule. This area of the city was valuable because the fortification reserved space, and it was possible to partly design these empty spaces for the public in the still small city.

The historical city and fortification architecture of Split consists of (fig. 2): 1. walls of the Ancient Emperor Palace with the towers, three land gates and one which was opened to the sea façade where the cryptoporticus promenade of Diocletian was at the upper Palace floor level; 2. the Lazaretto or the bay and harbour; 3. 'Pjaca', town square; 4. fortifications around the town; 5. the Fort of Gripe; 6. the suburbs today called 'Varoš' (6a), 'Dobri' (6b), 'Manuš' (6c) and 'Lučac' (6d); 7. the hill with the Jewish cemetery; 8. the fortifications of Katalinić; 9. Sustipan hill with town cemetery (Borčić [1], Marić and Bojanić Obad Šćitaroci [2]).

During the $20^{\text {th }}$ century the city of Split rapidly spread through the whole peninsula. In this urban expansion of the $20^{\text {th }}$ century, open spaces with parks and recreation in the city have been reduced to a minimum, leaving only the western end of the peninsula as an empty space. This area had been without vegetation since the Ottoman invasion in the $16^{\text {th }}$ and $17^{\text {th }}$ century, until afforestation in the first half of the $20^{\text {th }}$ century took place. Now the park-forest is called Marjan and it is the only larger area of pathways and nature in the city.

This lack of parks, together with the Mediterranean climate, has influenced the fact that streets have become the real public places of Split for people to stay and gather at, even more than squares.

\subsection{Theoretical background: streets as public places}

Sometimes no attention is given to the distinction between the terms 'space' and 'place' in a non-scientific language of architecture, urban design and planning. As written in the Introduction by Hubbard and Kitchin: "In popular discourse, space and place are often regarded as synonymous with terms including region, area and landscape" (Hubbard et al. [3]) which can be a great problem in a lot of disciplines. The general idea of creativity in design professions is that under the same assignments there is more than one solution, which is the reason why urban and architectural competitions are interesting and still applied. This basically means that the same space can be transformed into different places (Tuan [4]).

The second part of the twentieth century changed the context of points of view for a lot of disciplines. There was a spatial turn in social sciences and 
cultural turn in geography. In that way, physical geographers see space as "straightforwardly empirical, objective and mappable", but human geographers until the 1970s considered space as "a neutral container, a blank canvas which is filled in by human activities". Place is, therefore, approached as a certain space "authentic, close and lived spaces" (Hubbard et al. [3]).

One of the first social turns in urban design and theory can be seen after the 1960s. It was the time when authors like Jane Jacobs, William H. White, Christopher Alexander, Kevin Lynch and Donald Appleyard, including others, started to talk about urban problems with a large interest in cities and public life. In the $21^{\text {st }}$ century, an ecological turn is also evident, with predominant topics of pollution and sustainability, liveability, health and security (Gehl and Svarre [5], Gehl and Gemzoe [6]).

The sustainability approach and the social turn resulted in a new discussion of the human scaled city with pedestrian orientation. This discussion has already gained influence in theory, but more importantly it has also influenced design and construction.

\subsection{Walkspace as an urban background}

This paper is the continuation of the work done by authors T. Maric and B. Bojanić in the paper Walkspace - Linear Space and Motion in the City of Split for the journal Prostor (Space). 'Walkspace' is a research into urban walk spaces such as avenues and squares, public parks and promenades, including contemporary public spaces that build up the city. Such spaces are experienced mainly when walking around the city and are used for public gatherings, walking, strolling, and outdoor activities. The basic concepts dealt with in this paper are: 1. walking; 2. strolling for the purpose of recreation and leisure (but also learning, researching, and creating); 3. walkability; 4. walkspace as the space where we walk through; 5. walkscape as the spaces that we see and contemplate when walking around (Marić and Bojanić Obad Šćitaroci [7]).

The significance of walking in human culture is best described by F. Careri in his book Walkscapes: "By modifying the sense of space crossed, walking becomes man's first aesthetic act, penetrating the territories of chaos, constructing an order on which to develop the architecture of situated objects" (Careri [8]). At the beginning of the $21^{\text {st }}$ century (the age of digitalization following the $20^{\text {th }}$ century, the age of cars and computer technology) walking has become a central topic. Cities in current planning trends are viewed more as dynamic systems and less as formal and static configurations and constellations.

Squares, parks and districts known to us as traditional urban typologies are fading in their design meaning while contemporary city is shaped by infrastructure (indeterminate by space boundaries) and its network that envelops the whole city and more (Marić and Bojanić Obad Šćitaroci [2]).

By analysing the papers and conclusions of WALK21 conferences, we can assemble the story of today's problems, where streets can be seen as one of the place-making networks for the future pedestrian-friendly cities. Therefore, from the beginning (London, 2000) "talking the talk" is the confirmation of the importance of walking issues. Already in 2002 (San Sebastian) "steps towards 
liveable cities", the term human cities is explained with the goal that in these cities pedestrians come first. After that, the following was explored on conferences: walking as a mode of transport (Portland, 2003), cities for people (Copenhagen, 2004), everyday walking culture (Zürich, 2005), walkability (Toronto, 2007), sustainable and vibrant healthy communities (Barcelona, 2008), active living (New York, 2009), transformations and encouraging walking (Vancouver 2011, Munich 2013).

In the research paper mentioned at the beginning of this chapter, WalkspaceLinear Space and Motion in the City of Split, a walkspace was divided into three models, with streets as one of those models. All streets are pathways of the city, from pedestrian promenades and streets, through lungomare coasts to city avenues and boulevards as the urban arteries. Altogether, they are linear connections in the city with directed motion and the possibilities of changing directions (Marić and Bojanić Obad Śćitaroci [7]). These possibilities of changing directions or turning from one way are a basis for network planning. On a large scale, a network can determine the structure of a city, but on a human scale network can be focused it can be focused on public places to stay at - urban walkspace. This network of public places is a model for transforming and creating streets as more than just places of motion in a city.

\section{Spatial context: observing pathways of the city of Split}

The context of the city of Split can be described as human scaled spaces, because its distances are human and walkable; its character is not monumental. Split has a population of around 180,000 inhabitants, but is topographically limited to the peninsula and therefore it hasn't spread in width, but it is rather built as a more compact city. As a Mediterranean city with a great number of sunny days, its setting makes a strong demand for pleasant walkways. Walkways can be a part of a different kind of ambient with various usages and suggested activities, from a bench, playground to a tree and a store.

Main historical pathways which had led to the city became the first roads during the city's growth and now they are avenues with rows of trees as a dominating urban and design element. If we map these rows, the main linear network along the Split peninsula would be visible. Park-forest Marjan is the hill of the city and its dominant artificial compositions are pathways, walkways, recreational routes, stairs and shared space of roads. The newest planned part of the city is called Split III and its concept is based on a neighbourhood pedestrian street. This street is a polygon for vivid life and social interaction. Its main orientation is not north-south or east-west, but rather it is oriented to topography and the Diocletian's Palace, which is in small deviation from the four cardinal directions. All three systems of walkways - avenues, Marjan forest and Split III - are left for the future research and are not the main subject of this paper. The focus will be placed on the city core with a pedestrian zone and its connections to these other urban parts, like lungomare system, streets through the Palace and places around the Palace. 


\section{Formation of networks: case study of Split}

\subsection{Transformation of Split public space}

Cardo-decumanus transformation was the first important network-making process at the location of Split. Its dimensions and partially its direction have changed significantly through history. Nevertheless, these two vital streets and the peristyle at their meeting point were the beginning of the future network of the city in the former Diocletian's Palace $\left(7^{\text {th }}-12^{\text {th }}\right.$ century). Through the medieval growth, economy boom and new autonomy - the civitas, decumanus street was continued to the west as the path to the town square Platea sancti Laureti or 'Pjaca', or 'Narodni trg' (13 ${ }^{\text {th }}$ and $14^{\text {th }}$ century) (Borčić [1]).

The second important transformation appeared under the short French rule (1806-1813), when the fortifications were partially removed, new streets were formed, parks were formed or planned and areas of the coast were added. In the 19 th century the city had four suburbs. Some have developed along the pathways to the city from north and east. The suburb 'Varoš' to the west was the biggest and it developed in correlation with the topography of the slopes of the Marjan hill. This is still the core of the city on the Split peninsula (Krajnik [9]).

New transformations during the $20^{\text {th }}$ and $21^{\text {st }}$ century dealt more with the design and traffic regulation. That is why 'Riva' and Marmontova Street are now pedestrian urban places which have influenced the current creation and further development of the Split lungomare.

\subsection{Doors, passages and stairs}

Cardo and decumanus streets used to connect just the entering doors on the fortification walls of the Diocletian's Palace. Nowadays, the doors are ambiental urban elements which suggest a new character in the public space of the city center. They are the connectors of urban sequences important for giving variety to the motion experience. Unlike Middle European cities, which are famous for their passages, Split has short transitional spaces or passages formed like the doors of the Palace. The passages are intermediate elements rather than places to stay, which connect spaces of public street network (fig. 4).

A similar kind of urban elements and connectors are stairs. Split's topography is composed of several hills. Therefore, stairs as urban elements are functionally important and sometimes they dominate the neighbourhoods (fig. 5) in various ways, for example: 1. 'Marjanske skale' in the promenade of the park-forest with aesthetical and historical value, 2. west part of Senjska Street in 'Varoš' as the street of stairs towards the Marjan hill, 3. the beginning of the street with valuable vista, e.g. Glagoljaška street.

\subsection{Streets, squares and parks}

The most important traditional typologies of public space are streets, squares and parks. As such, together they are the strongest elements that form and direct the public network of the cities (Moughtin and Mertens [10]). 


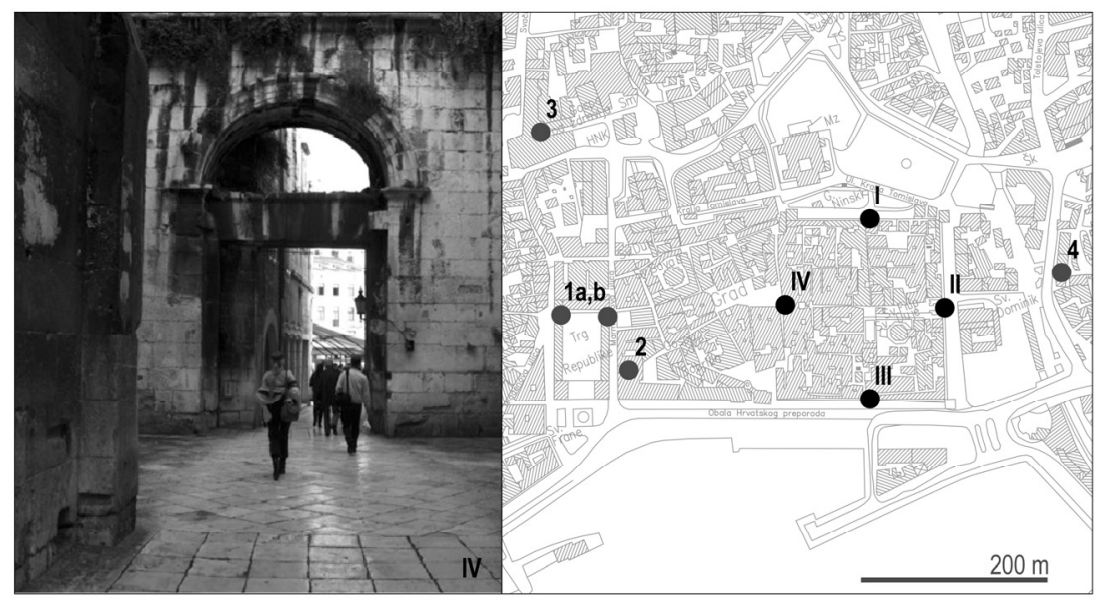

Figure 4: Doors, black: I - Porta Aurea (Golden Gate, north), II - Porta Argentea (Silver Gate, east), III - Porta Aenea (Bronze Gate and entrance to the basements of the Palace, south); IV - Porta Ferrea (Iron Gate, west); Passages, grey: 1a,b - Republic square; 2 - Ilićev passage; 3 - Porinova (HNK - National theatre); 4 - Passage to the Lučac.

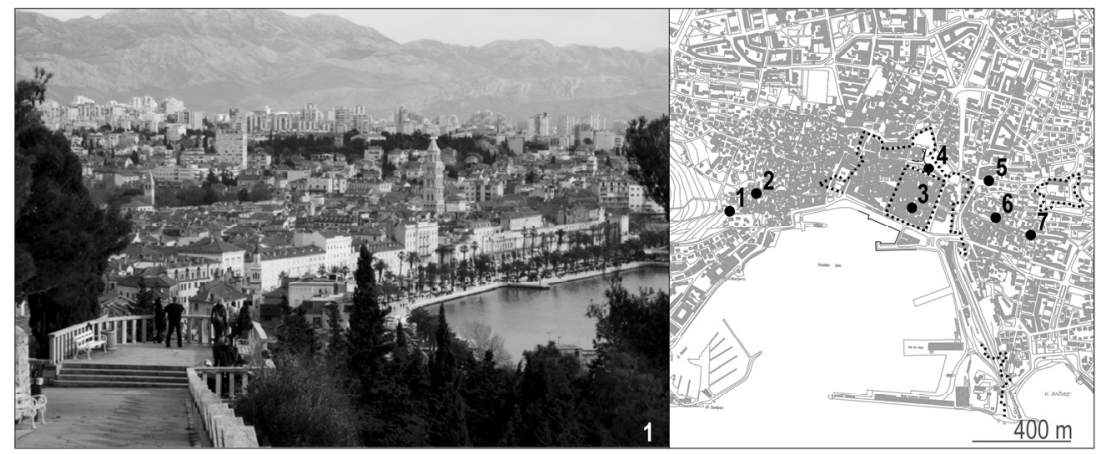

Figure 5: Vista from Marjan hill of the 'Riva' with the map of stairs: 1 - Botic and Marangunic promenade; 2 - Senjska street of stairs; 3 - stairs form Peristil to the Vestibul and basements of the Palace, 4 - stairs to the park 'Đardin'; 5 - stairs in Glagoljaska street which leads to the fort Gripe; 6, 7 - stairs in Radunica pedestrian street of Lucac.

The parks of Split are not numerous and they are small in scale compared to the city population and density. Marjan park-forest is in that context the "central park of Split" (fig. 5). Nevertheless, or even due to that fact, every small park or "pocket landscape space" is contributing to the pleasant microclimate in the network of public places. 
Marmontova Street is an example of a pedestrian street full of public life and with pleasant width. Its width is in-between narrow canals of streets that we find in historical cores and normal width of the contemporary street, where there is a road for vehicle traffic and pedestrian sidewalks with parking. The real importance and strength of this street is its connecting position. It connects two vital urban public spaces: 'Gaja Bulata Square' and 'Riva' (fig. 6). Due to its perpendicular orientation to the coast it has vista of the sea to the south, which makes it even more attractive. Recently redesigned 'Riva', and 'West Coast Waterfront', a recently finished project, together with the 'East Coast Traffic Harbour' create a system of lungomare which will in the future connect the whole city on the southern coast. It will also connect Marjan park-forest with the periphery. The important and vital elements in this linear system are tree lines and specific smaller places, which are different and unique, like the pedestrian pier between 'West coast' and 'Riva'.

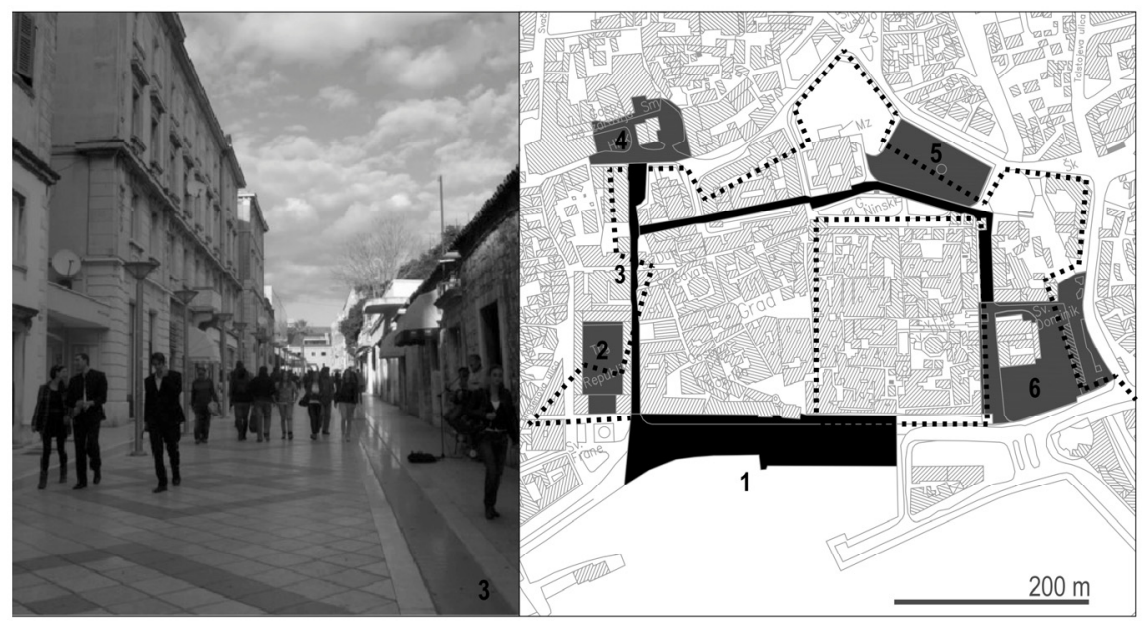

Figure 6: Marmontova street in a system of public places where fortifications were demolished. System is formed by streets (black), squares and park (grey): 1 - Riva (also a base of the lungomare system); 2 - Republic square on higher level than 'Riva'; 3 - Marmonotva street, for pedestrians; 4 - Gaje Bulata square; 5 - Strossmayer Park ('Đardin'); 6 - central market ('Pazar').

The network of public places in Diocletian's Palace consists of narrow pedestrian streets with small broadenings. There is a tendency to transform these broadenings in the street profile into café terraces, which are especially pleasant during the warm summer days. 


\section{Network valorisation}

Today's network of public places in the centre of Split can be divided into inner and outer network, regarding the relation to the Diocletian's Palace as the unique historical base point in the urban development.

The inner network is the open public space of the Palace itself together with the western medieval urban growth. Gates and passages are primary defining connection-boundary elements of this network. The peristyle square is its basic social and tourist point. The streets here have been narrow since the medieval transformation and every wider part of the street is considered as a small gathering place and addition to the inner network. These broadenings have the potential for the future transformation and re-definition, which is a process that has already started. The characteristic of the inner public network of Split is that it is formed in several levels, again as added value. From the street level where the peristyle is positioned the stairs lead either to the upper level through the vestibule or to the basements of the Palace.

The outer network has several types, regarding the ways in which the inner network is connected to the rest of the city. The evident ones are: 1. linear continuity of the cardo-decumanus direction from the gates of the Palace with streets and small squares as dominating connection elements, 2. ring system of streets, squares and parks around the Palace, 3. lungomare system with specific urban areas in development. Characteristic of these networks is their orientation in relation to the Palace and the sea (perpendicularity or parallel), which opens up numerous vistas on either the sea, park-forest hill of Marjan, mountains in the north or Salona archeological site of the former, large, Roman city. Lungomare system is becoming the main social and touristic space of the outer network.

\section{Conclusion for future research}

In the city of Split, as in other Mediterranean cities, streets are significant public places where people gather and spend their time. Therefore it is important to preserve human scale in these cities with special orientation to the pedestrian issues. Walkspace of the city should be planned as a network in order to preserve the human scale and improve connectivity. Improved connectivity in areas with cultural heritage is especially important for the preservation and giving added values to heritage surrounding.

In the context of Split, this paper shows: (1) that the cultural heritage like historical walls, fortifications and other elements play a significant role in creating urban street networks of public places (inner and outer). These networks have been developed out of transformations and re-definitions of empty open spaces (2). A variety of public places which was created gives new values to the network that connects Split centre to the city (3) by elements of squares, plazas, streets, passages, pocket-parks, stairs and historical doors and walls.

The significance of this research for the future is in defining the possibilities for improvements in the urban connectivity of Split. The benefits of further urban transformations in networks of public places, if they are considered with 
planning strategies, can result in the improvement of urban sustainability and connectivity, better social relations, increased design values and more diverse experience through space, motion and time.

\section{References}

[1] Borčić, G., Riva dozvana iz zaborava, Muzej grada, Split, 2006.

[2] Maric, T. \& Bojanić Obad Šćitaroci, B., The City of Split and Marjan Peninsula Interaction, International Workshop Architecture, Society and Education, Barcelona, 2012.

https://www.pa.upc.edu/Varis/altres/arqs/congresos/copy of International -Workshop-COAC-Barcelona-2012---Jornadas-Cientificas-COACBarcelona-2012/comunicacions/sesion-9-session-9/MARIC-T-BOJANICB.pdf/view.

[3] Hubbard, P., Kitchin, R. \& Valentine, G., Key Thinkers on Space and Place, SAGE Publications, London, 2nd ed., pp. 1-17, 2011.

[4] Tuan, Y.-F., Space and Place - The Perspective of Experience, University of Minnesota press, Minneapolis and London, pp. 1-18, 161-198, 2008.

[5] Gehl, J. \& Svarre, B., How to Study Public Space, Island Press, Washington, Covelo, London, 2013.

[6] Gehl, J. \& Gemzoe, L., New City Spaces, The Danish Architectural Press, Copenhagen, 3rd ed., 2nd print, 2006.

[7] Marić, T. \& Bojanić Obad Śćitaroci, B., Walkspace: Linear Space Motion in the City of Split, Prostor, Zagreb, 1(43), pp. 118-131, 2012, http://www.arhitekt.unizg.hr/prostor/default.aspx.

[8] Careri, F., Walkscape - walking as an aesthetic practice, "GG"Land\&Scape Series, Vol. 1, Ed. 5, Barcelona, 2007.

[9] Krajnik, D., Preobrazba bastionskih utvrđenja u europskim i hrvatskim gradovima, Arhitektonski fakultet Sveučilišta, Zagreb, Acta architectonica. Scientific monographs, no. 8, 2011.

[10] Moughtin, C. \& Mertens, M., Urban Design - Street and Square, third edition, Architectural Press, an imprint of Elsevier, Oxford, 2003. 